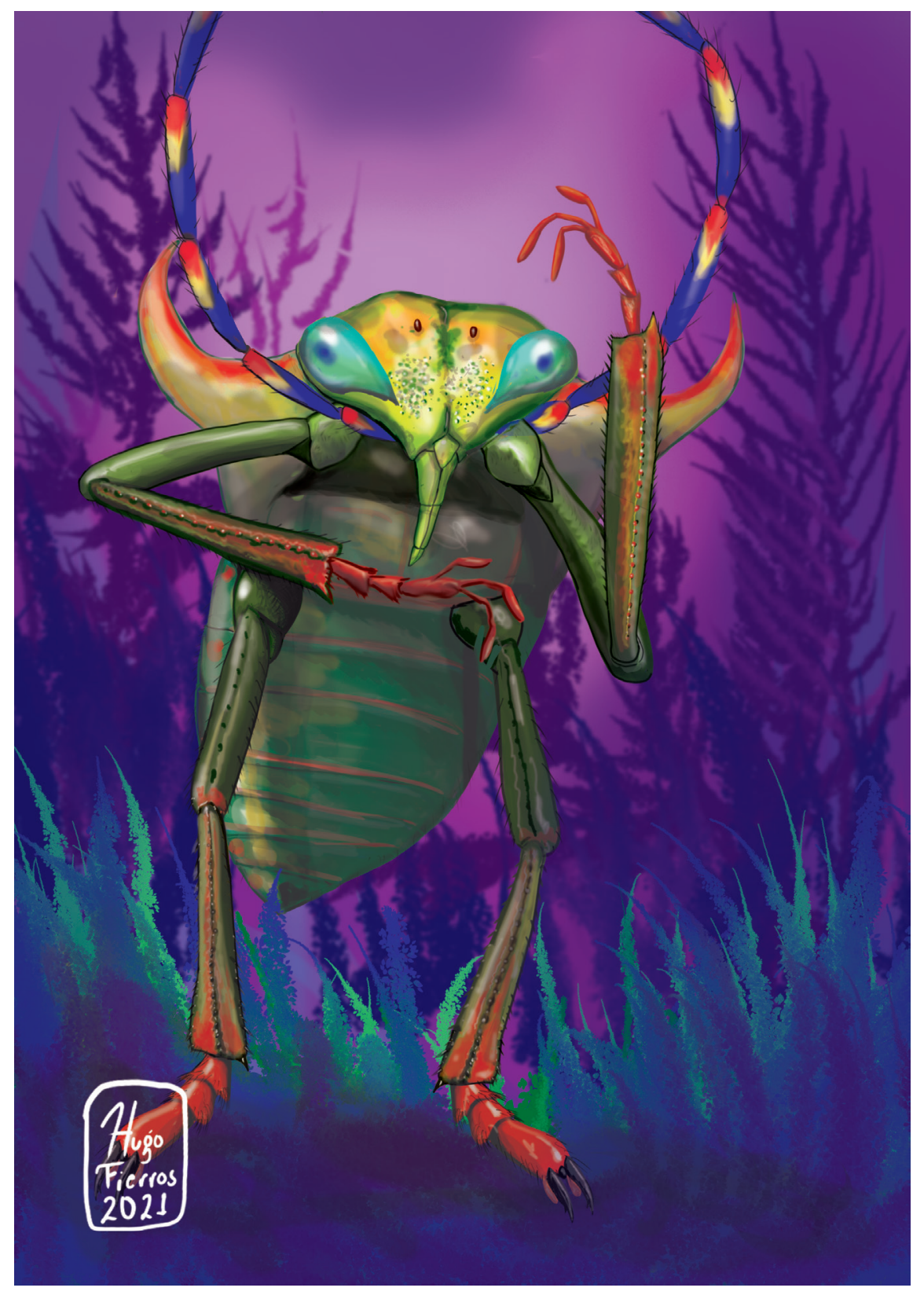

Dugesiana, Año 29, No. 1, (enero-junio, primer semestre 2022), es una publicación semestral, editada por la Universidad de Guadalajara, a través del Centro de Estudios en Zoología, por el Centro Universitario de Ciencias Biológicas y Agropecuarias. Camino Ramón Padilla Sánchez \# 2100, Nextipac, Zapopan, Jalisco, Tel. 37771150 ext. 33218, http://148.202.248.171/dugesiana/index.php/DUG/index, glenusmx@gmail.com. Editor responsable: José Luis Navarrete-Heredia. Reserva de Derechos al Uso Exclusivo 04-2009-062310115100-203, ISSN: 20079133, otorgados por el Instituto Nacional del Derecho de Autor. Responsable de la última actualización de este número: José Luis Navarrete-Heredia, Editor y Ana Laura González-Hernández, Asistente Editorial. Fecha de la última modificación 1 de enero de 2022, con un tiraje de un ejemplar.

Las opiniones expresadas por los autores no necesariamente reflejan la postura del editor de la publicación.

Queda estrictamente prohibida la reproducción total o parcial de los contenidos e imágenes de la publicación sin previa autorización de la Universidad de Guadalajara. 
Artículo

\title{
Cundinablissus callejai, a new genus and new apterous species of Blissidae (Hemiptera: Heteroptera: Lygaeoidea) from Colombia
}

\section{Cundinablissus callejai, género nuevo y especie áptera nueva de Blissidae (Hemiptera: Heteroptera: Lygaeoidea) de Colombia}

\author{
Harry Brailovsky \\ Departamento de Zoología, Instituto de Biología UNAM, Apartado Postal 70153, Ciudad de México, 04510, \\ México; e-mail: coreidae@ib.unam.mx. ORCID: https://orcid.org/0000-0001-7456-5678
}

\begin{abstract}
The new genus Cundinablissus gen. nov., with the single species C. callejai sp. nov., is described from Colombia. A key to the known genera of Blissidae with apterous or micropterous condition from the Western Hemisphere is included.

Key words: Insecta, Heteroptera, Blissidae, new genus, new species, apterous, key, Neotropical Region
\end{abstract}

\section{RESUMEN}

Un nuevo género Cundinablissus gen. nov., con una sola especie C. callejai, sp. nov., de Colombia son descritas. Se incluye una clave para separar los géneros ápteros y micropteros de Blissidae del Continente Américano.

Palabras clave: Insecta, Heteroptera, Blissidae, género nuevo, especie nueva, áptero, clave, región Neotropical.

The Blissidae, previously treated as a subfamily of the Lygaeidae (Henry 1997), is a worldwide group of phytophagus Heteroptera found in all zoogeographic regions (Henry and Sweet 2015). A total of 52 genera of Blissidae are known in the world; of these 21 occur in the Western Hemisphere (Dellapé and Henry 2020). Slater (1979) monographed the family, providing diagnoses for 46 genera, a phylogenetic analysis, and keys to the genera and many of the species (Henry and Sweet 2015). Later, Slater (1986) described Aulacoblissus from Venezuela (one species), Ŝtys (1991) added Howdenoblissus from Colombia (one species), Brailovsky and Barrera (2012) described Napoblissus from Ecuador (one species), and Brailovsky (2015) described Barrerablissus from Ecuador (one species) and provided an update key to the six apterous or micropterous New World genera of the family. More recently, Henry and Sweet (2015) added Wheelerodemus from the United States of North America (one species), and Minghetti et al. (2020) described Tympanoblissus from Ecuador (one species).

Slater (1995) added a new species of Praetorblissus from Costa Rica, Dallapé and Montemayor (2009) a new species of Ischnodemus from Peru, and Cervantes Peredo and Brailovsky (2013) a new species of Praetorblissus from México. Wheeler (2016) provides additional information about the genus Wheelerodemus.

In this work, the new blissid genus Cundinablissus and its species $C$. callejai are described, based on apterous specimens collected in Colombia. Also, a key to the apterous and micropterous genera of Blissidae from the Western Hemisphere is presented.

\section{MATERIALS AND METHODS}

The following abbreviations are used for the institutions cited here: Instituto de Biología, Universidad Nacional Autónoma de México, México (UNAM); Universidad Nacional de Colombia, Bogotá, Colombia (UNDC). The measurements were obtained using eyepiece micrometer. All measurements are in mm. External and genital structures were studied with a stereoscopic microscope (model Zeiss Stereo Discovery 8). Pictures were taken with a Nikon D200 camera. To remove soft tissues, genitalia were macerated in hot $10 \%$ solution of $\mathrm{KOH}$ for 5 minutes, rinsed in distilled water, and dissected under stereoscopic microscope Leica MX8.

\section{RESULTS \\ TAXONOMY \\ Cundinablissus gen. nov.}

Figures 1-5

http://zoobank.org/02BE15DC-BDAA-4504-AA4CAB6CD6005883

Type species. Cundinablissus callejai sp. nov., here designated.

Diagnosis. This new genus (Figs. 1-5) is recognized by the combination of open fore coxal cavities, body entirely shiny, without pruinose areas, presence of a ocellus, apterous condition, abdomen lacking a stridulitrum, fore 
femur mutic, and the small size and broad, sublinear body form.

Description. Length of males 3.58; females 4.20. Apterous specimens. Body relatively broad, sublinear, shining, without pruinose area; ground color uniformly reddish brown; pubescence simple, scattered, with decumbent and upstanding silvery setae; shallow to deep scattered punctures on head, anterior lobe of pronotal disc, scutellar disc, mesonotum, metanotum and dorsum of abdominal segments; shallow sparse punctures on abdominal sterna; connexival segments and pleural abdominal margins impunctate.

Head. Non-declivent, nearly prognant, wider than long; tylus almost reaching apex of antennal segment I, apically globose, in lateral view higher and longer than jugum; vertex moderately flat; antenniferous tubercle short, truncate; antennal segment I broad, barrel-shaped; segments II and III cylindrical, IV fusiform; antennal segment I the shortest, IV the longest, and II longer than III; ocelli closer to compound eyes than to each other; eyes hemispheric, protruding, not touching anterior margin of pronotum; maxillary plates and genae without modifications; buccula short, apically rounded, not extending base of antennal segment I; rostrum surpassing fore coxae, reaching middle third of mesosternum; rostral segment I reaching anterior margin of prosternum; rostral segment II the longest, I and III subequal, and IV slightly longer than I and III.

Thorax. Pronotum. Wider than long; subrectangular, with barely indicated short collar, broadly rounded; pronotal disc below calli with shallow concavities indicating the limits of the anterior lobe; posterior lobe of pronotal disc conspicuously wrinkled; anterolateral margins evenly convex to nearly parallel-sided, emarginated, broadest at level of calli; anterior margin concave; calli almost flat, foveate; frontal and humeral angles rounded; posterior margin straight. Mesosternum without median furrow; mesonotum straight, strikingly transverse, lateral borders parallel and external margins swelling, slightly folded downward; metanotum simple, not subdivided, straight, strongly depressed at midline, with lateral margins exposed, conspicuously swelling, folded downward, and clearly visible in dorsal position; metathoracic scent gland auricle elongate, slightly rounded distally, ear-like, and moderately curving posteriorly (Fig. 2); evaporative surface transversally furrowed, extending to posterior margin of metapleuron, and extending onto mesopleuron, occupying the posterior margin.

Legs. Fore coxal cavities open, separated by a wide rounded prosternal projection; all trochanters terminating into ventrodistal subspinose axial projection adpressed to the femora; all femora short, moderately incrassate, mutic; tibiae mutic; fore tibiae slightly enlarged distally.

Scutellum. Wider than long; lacking a median elevation.

Hemelytra. Apterous.

Abdomen. Broad, parallel-sided, slightly convex, wider than thorax; abdominal terga almost flat; connexivum raised above tergum, with prominent spiracles, placed far from upper border; abdominal spiracles II to VI dorsal, VII and VIII ventral; abdominal spiracle II closer to anterior border, III to VIII almost at midline; abdominal sterna lacking a stridulitrum.

Integument. Almost glabrous; dorsal surface and abdominal sterna with sparse, elongate and upstanding silvery setae; head ventrally and thorax glabrous; antennal segments and legs with moderately dense, upstanding silvery setae.

Male genitalia. Genital capsule simple, globose; posteroventral edge entire, rounded (Fig. 4). Paramere. Like in figure 5.

Female genitalia. Abdominal sterna III-V uniformly developed, straight; abdominal sterna VI constricted at midline; sternite VII with fissura along midline. Gonocoxite VIII enlarged, subrectangular; in lateral view with upper and external borders slightly convex, in caudal view with inner borders straight and widely opened; laterotergite VIII quadrate, spiracle visible; laterotergite IX rectangular, slender, longer than laterotergite VIII, with inner and outer borders straight (Fig. 3).

Differential diagnosis. This new genus shares the extreme microptery to apterous condition and fore coxal cavities open with other eight genera: (Aulacoblissus Slater, Barrerablissus Brailovsky, Heteroblissus Barber, Howdenoblissus Ŝtys, Napoblissus Brailovsky and Barrera, Praetorblissus Slater, Tympanoblissus Dellapé and Minghetti, and Wheelerodemus Henry and Sweet). Although Ischnodemus Fieber has a similar wing condition as the above-mentioned genera the fore coxal cavities are closed.

With this group of nine genera Cundinablissus gen. nov., shares the presence of ocelli with Barrerablissus, Heteroblissus, Praetorblissus, Tympanoblissus, and Wheelerodemus. Of these. Heteroblissus and Tympanoblissus can be distinguished by the presence of a stridulitrum in the abdomen. Furthermore Barrerablissus, Praetorblissus and Wheelerodemus exhibit micropterous condition. Cundinablissus is the only known genus, within group, with apterous condition.

Aulacoblissus, Howdenoblissus, and Napoblissus share the absence of ocellus. In Aulacoblissus and Napoblissus the fore femur are ventrally armed and the hemelytra are micropterous. In the other two species the fore femur are mutic and apterous. Cundinablissus, has ocellus absent in Howdenoblissus.

Etymology. Named for its occurrence in the Cundinamarca Department, Colombia.

Key to the known apterous or micropterous genera of Blissidae from the Western Hemisphere (modificated from Brailovsky and Barrera 2015)

1. Fore coxal cavities closed behind. Ischnodemus Fieber

- Fore coxal cavities open ............................. 2 


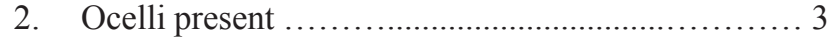

Ocelli absent .............................................. 8

3. Abdomen with stridulitrum ........................... 4

Abdomen lacking a stridulitrum .................... 5

4. Abdominal venter with a prominent stridulitrum on sternites III-IV; macropterous or micropterous; body completely subshining, lacking pruinose areas

Heteroblissus Barber

Abdominal tergites I-II with tymbal organs; apterous; body not entirely shining or subshining with pruinose areas Tympanoblissus Dellapé and Minghetti 5. Apterous...................... Cundinablissus gen. nov. - $\quad$ Micropterous ............................................... 6 6. Fore femur mutic; body elongate, slender, small size, male 3.40-3.84, female 4.28-4.80; prosternum with a median keel .................. Wheelerodemus Henry and Sweet

Fore femur armed; body relatively robust, elongate, longer, male 4.68-12.96, female 8.08; prosternum without median keel.

7. All femora multispinose; metathoracic scent gland auricle strongly curving anteriorly ... Praetorblissus Slater

Fore femur with two ventral spines; middle and hind femora mutic; metathoracic scent gland auricle moderately curving posteriorly ................. Barrerablissus Brailovsky 8. Apterous; fore femur mutic .... Howdenoblissus Ŝtys - $\quad$ Micropterous; fore femur ventrally armed .......... 9 9. Fore femur armed below and distally with two spines; median mesosternal furrow deep; scutellar disc with median elevation .. Napoblissus Brailovsky and Barrera

Fore femur armed below and distally with a single minute spine median mesosternal furrow absent; scutellar disc flat, lacking a median elevation ... Aulacoblissus Slater

\section{Cundinablissus callejai sp. nov.}

Figures 1-5

http://zoobank.org/FF9497C0-6398-439D-9D3D5ED7DAEE67F1

Type locality. Colombia, Cundinamarca Department, Cabrera.

Type material. HOLOTYPE: male, COLOMBIA: Cundinamarca, Cabrera, Vereda de Hoyerias, $3390 \mathrm{~m}$, 3918'N-74³94'W, 19-22-X-2014, C. Dumar (t.winkler) (UNDC). PARATYPES: same data as holotype: 1 male, 2 females, (1 female UNAM, 1 male, 1 female UNDC). 1 male, 1 female, COLOMBIA: Cundinamarca, Chipaque, Vereda Las Fruticas, collecting in grass, $3570 \mathrm{msnm}$, 4³44'N-79095'W, 9-12-X-2014, C. Dumar (1 male UNAM, 1 female UNDC).

Description. Male (holotype). Body above and below shining, without pruinose areas. Dorsal coloration. Nearly uniformly reddish brown, becoming castaneous orange on tylus, anterolateral margins of meso-, and metanotum, and apex of scutellum; antennal segments I-III castaneous orange, IV dark reddish brown with basal joint castaneous orange; abdominal segments II-VII shiny reddish orange.

Ventral coloration. Nearly uniformly reddish-brown, to castaneous- orange on rostral segments I-IV (apex of IV black), acetabulae, coxae, and trochanters; femora and tibiae shiny castaneous orange; tarsi pale yellow orange; evaporative surface dull gray; abdominal sterna and genital capsule shiny reddish orange.

Genitalia. Genital capsule simple, globose; posteroventral edge entire, rounded (Fig. 4). Paramere. Like in figure 5.

Measurements. Male holotype. Body length 3.58 $\mathrm{mm}$. Head length $0.42 \mathrm{~mm}$; width across eyes $0.80 \mathrm{~mm}$; interocular space $0.50 \mathrm{~mm}$; preocular distance $0.32 \mathrm{~mm}$; interocellar distance $0.23 \mathrm{~mm}$; length of antennal segments: I, $0.20 \mathrm{~mm}$; II, $0.37 \mathrm{~mm}$; III, $0.31 \mathrm{~mm}$; IV, $0.52 \mathrm{~mm}$; length of rostral segments: I, $0.28 \mathrm{~mm}$; II, $0.30 \mathrm{~mm}$; III, 0.28 $\mathrm{mm}$; IV, $0.29 \mathrm{~mm}$. Pronotal length $0.58 \mathrm{~mm}$; width across humeral angles $1.22 \mathrm{~mm}$. Scutellar length $0.21 \mathrm{~mm}$; width $0.62 \mathrm{~mm}$.

Female. Coloration similar to that of male holotype. Body dorsally and ventrally uniformly dark reddishbrown, to dark castaneous-orange on tylus, middle third of scutellum, lateral margins of meso-, and metanotum, connexivum, pleural margins of abdominal sterna II-VII, and acetabulae; antennal segments I-III dark castaneous orange, IV dark reddish-brown; rostral segments I-IV dark castaneous orange; coxae, trochanters, and basal third of femora pale castaneous orange; femora, (except basal third), tibiae and tarsi dark castaneous orange; evaporative surface dull gray, strongly contrasting with adjacent shining reddish brown color.

Genitalia. Abdominal sterna III-V uniformly developed, straight; abdominal sterna VI constricted at midline; sternite VII with fissura along midline. Gonocoxite VIII enlarged, subrectangular; in lateral view with upper and external borders slightly convex, in caudal view with inner borders straight and widely opened; laterotergite VIII quadrate, spiracle visible; laterotergite IX rectangular, slender, longer than laterotergite VIII, with inner and outer borders straight (Fig. 3).

Measurements. Female paratype. Body length 4.20 $\mathrm{mm}$. Head length $0.45 \mathrm{~mm}$; width across eyes $0.83 \mathrm{~mm}$; interocular space $0.52 \mathrm{~mm}$; preocular distance $0.34 \mathrm{~mm}$; interocellar distance $0.27 \mathrm{~mm}$; length of antennal segments: I, $0.22 \mathrm{~mm}$; II, $0.42 \mathrm{~mm}$; III, $0.32 \mathrm{~mm}$; IV, $0.55 \mathrm{~mm}$; length of rostral segments: I, $0.29 \mathrm{~mm}$; II, $0.32 \mathrm{~mm}$; III, 0.28 $\mathrm{mm}$; IV, $0.30 \mathrm{~mm}$. Pronotal length $0.60 \mathrm{~mm}$; width across humeral angles $1.35 \mathrm{~mm}$. Scutellar length $0.27 \mathrm{~mm}$; width $0.71 \mathrm{~mm}$.

Distribution. Known only from the type locality.

Etymology. It is a pleasure to dedicate this new species to Dr. Ignacio Calleja distinguished Odontologist and friend for many years. Gender masculine.

\section{ACKOWLEDGMENTS}

I thank Fernando Fernández (Universidad Nacional de Colombia, Bogotá, Colombia) for the loan of the specimens herein described. Special thanks go to Ernesto Barrera 
(UNAM), for the photographs and to Diana Martínez Almaguer (UNAM) and Julio César Montero (UNAM) for the plates design.

\section{LITERATURE CITED}

Brailovsky, H. 2015. A new genus and species of Micropterous Blissidae (Hemiptera: Heteroptera: Lygaeoidea) from Ecuador. Zootaxa 4028(4): 583-588.

Brailovsky, H. \& E. Barrera. 2012. A remarkable new micropterous Blissidae (Hemiptera, Heteroptera, Lygaeoidea) from South America. Deutsches Entomologische Zeitschrift 59 (1): 43-45.

Cervantes Peredo, L. \& H. Brailovsky. 2013. First record of Praetorblissusfrom Mexico (Hemiptera: Heteroptera: Lygaeoidea: Blissidae), with the description of a new species associated with bamboo. Zootaxa 3683 (2): 197200.

Dellapé, P.M. \& S.I. Montemayor. 2009. Description of a new species ofIschnodemus from Peru, and the male and immature stages of I. subflavus (Hemiptera: Heteroptera: Lygaeoidea: Blissidae). Revista Mexicana de Biodiversidad 80: 687-691.

Dellapé, P.M. \& T.J. Henry. 2020. Lygaeoidea Species File. Version 5.0/5.0. Available from URL: https:// Lygaeoidea. SpeciesFile.org [Accessed April 2021].

Henry, T.J. 1997. Phylogenetic analysis of the family groups within the infraorder Pentatomomorpha (Hemiptera:

Recibido: 3 de octubre 2021

Aceptado: 24 de noviembre 2021
Heteroptera), with emphasis on the Lygaeoidea. Annals of the Entomological Society of America 49: 9-18.

Henry, T. J., \& M.H. Sweet. 2015. Wheelerodemus muhlenbergiae, a new genus and species of Blissidae (Hemiptera: Heteroptera: Lygaeoidea) from Oklahoma and Texas. Proceedings of the Entomological Society of Washington 117 (2): 151-161.

Minghetti, E., H. Braun, F. Matt, \& P.M. Dellapé. 2020. Tympanoblissus ecuatorianus Dellapé \& Minghetti, gen. et sp. nov, a new apterous genus of chinch bug (Hemptera: Blissidae) from Ecuador: the only known blissid with an abdominal mechanism for sound production. Austral Entomology 59: 535-540.

Slater, J.A. 1979. The systematics, phylogeny, and zoogeography of the Blissinae of the World (Hemiptera, Lygaeidae). Bulletin of the American Museum of Natural History 165 (1): 1-180.

Slater, J.A. 1986. Aulacoblissus, a new genus of micropterous Blissinae from Venezuela (Hemiptera: Lygaeidae). Florida Entomologist 69 (4): 661-665.

Slater, J A. 1995. The first species of Aradacrates from Malaya and a new species of Praetorblissus from Costa Rica (Heteroptera: Lygaeidae: Blissinae). Journal of New York Entomological Society 103 (3): 311-316.

Stys, P. 1991. First apterous genus and species of Lygaeidae Blissinae (Heteroptera). Acta Entomologica Bohemoslovaca 88: 265-271.

Wheeler, A.G. Jr. 2016. Wheelerodemus muhlenbergiae Henry and Sweet (Hemiptera: Lygaeoidea: Blissidae): distribution, host plants, and seasonality. Proceedings of the Entomological Society of Washington 118 (4): 617 628. 


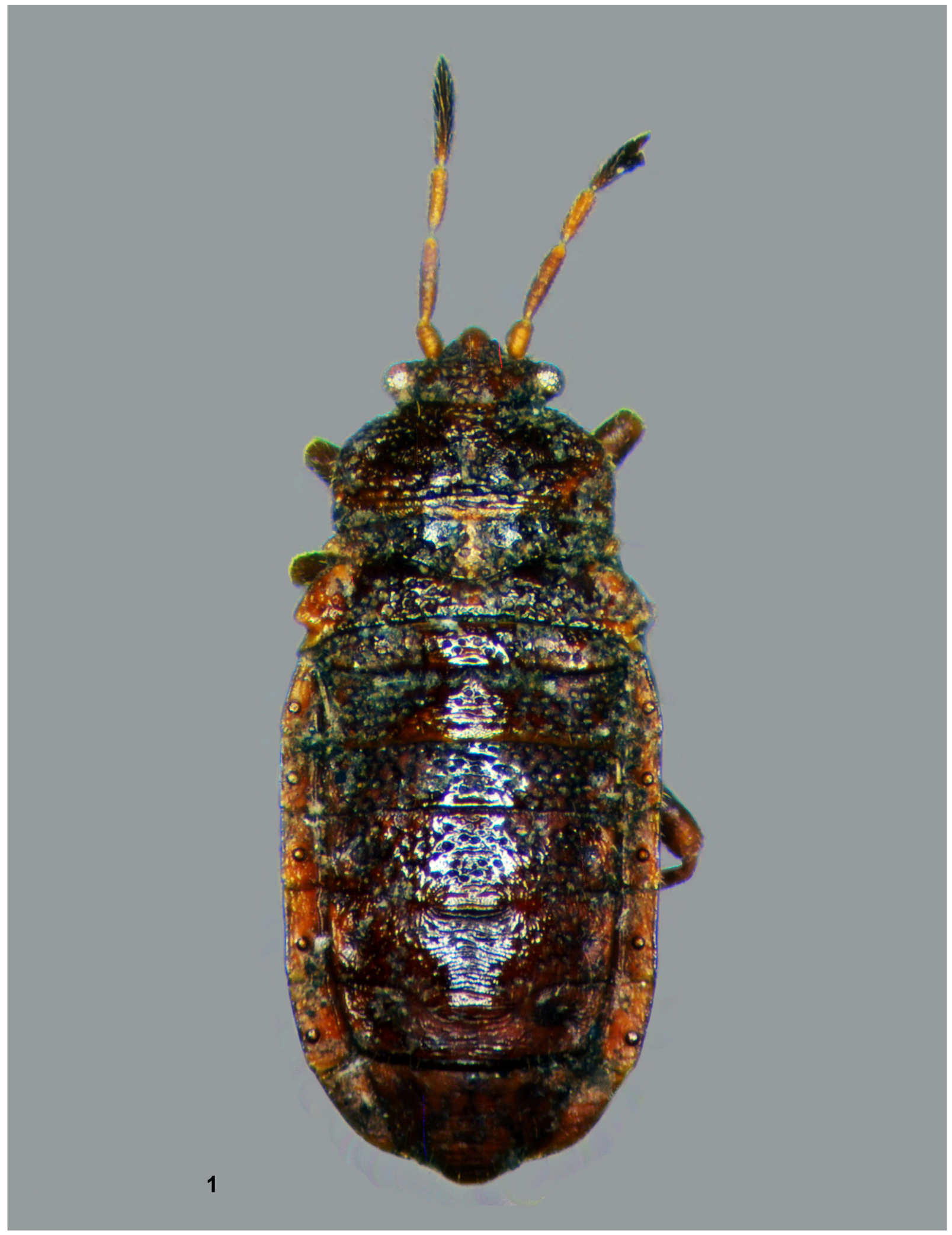

Figure 1. Dorsal view of Cundinablissus callejai gen. nov., sp. nov. 


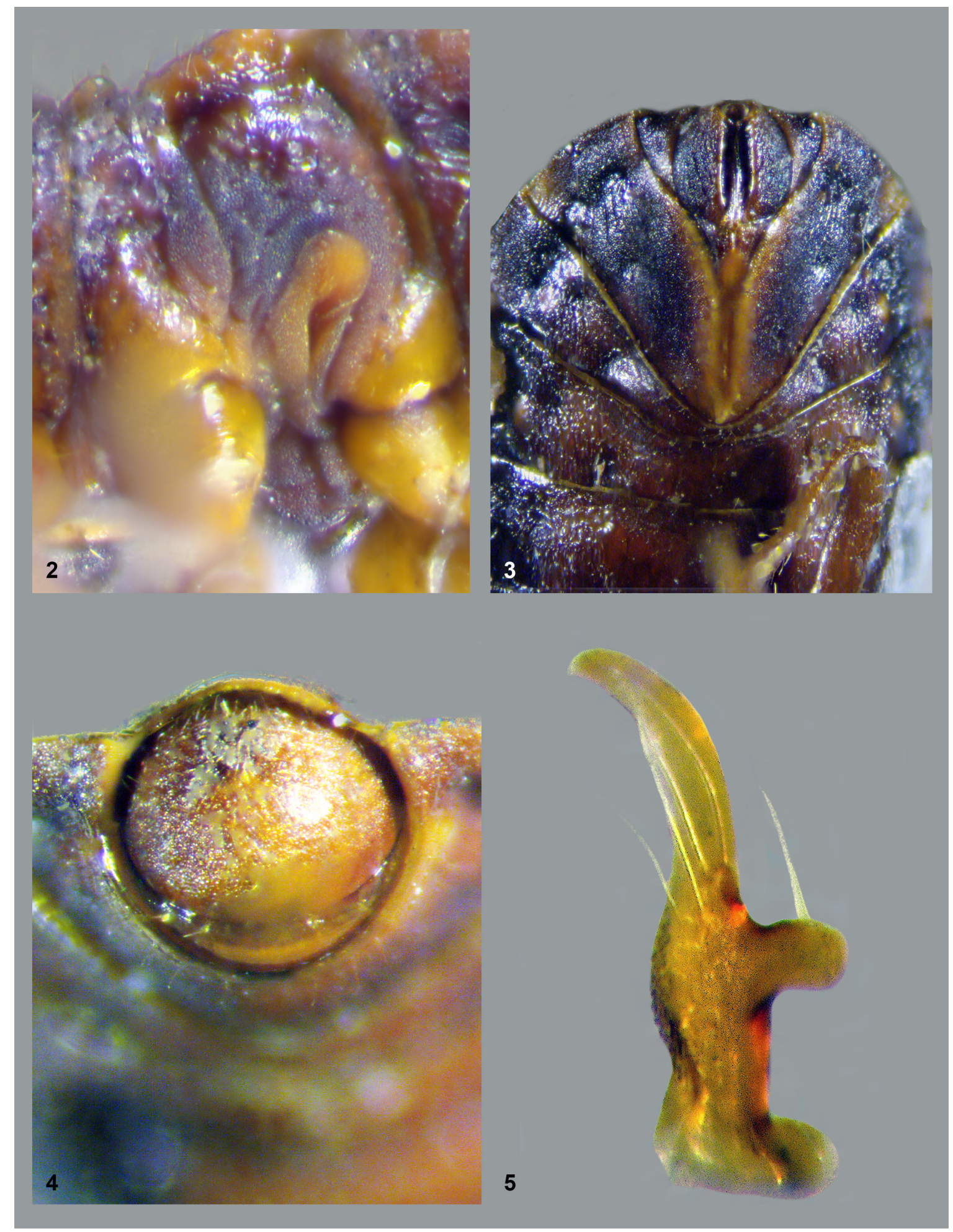

Figures 2-5. Cundinablissus callejai gen. nov., sp. nov. 2. Metathoracic scent gland auricle. 3. Female genital plates. 4. Male genital capsule in caudal view. 5. Paramere. 